\title{
ASSESMENT OF TRENDS IN THE SHARE OF EXPENDITURE ON SERVICES AND FOOD IN THE VISEGRAD GROUP MEMBER STATES
}

\author{
Mateusz Jankiewicz* \\ Nicolaus Copernicus University \\ Michal Bernard Pietrzak \\ Nicolaus Copernicus University
}

\begin{abstract}
The subject of the article concerns changes in the structure of consumption in the Visegrad countries in the years 1996-2016. The focused was on expenditure on services and food expenditure of households in the Czech Republic, Poland, Slovakia and Hungary. The systematic improvement of the socio-economic situation and institutional changes in the Visegrad Group countries resulted in an increase in expenditure on services and food. This contributed to changes in the structure of household consumption, where the share of expenditure on services in final expenditure increased in the examined period in each of the countries studied, and the share of expenditure on food systematically decreased. The main research objective of the article is to identify trends in the share of household expenditure on selected types of goods in their final expenditure. The different trends in the shaping of expenditure shares for goods considered in the article result from their different nature, where services are a higher order good, while food is a good satisfying basic existential needs of man. The study also attempted to determine the limit values of the share of expenditure on services and the share of expenditure on food in the structure of household consumption in selected countries. The limit values were determined for both types of goods on the basis of estimation of parameters of the Törnquist function of the first type. The limit values established in the study should be treated as the saturation level for the share of goods that the countries are able to achieve with the current trends in their socio-economic development.
\end{abstract}

Keywords: Households consumption structure; Services expenditure; Food expenditure; Törnquist function; Visegrad group.

Received: 1 November 2019

Accepted: 15 June 2020

\section{INTRODUCTION}

The subject of the article concerns the development of the share of expenditure of selected goods in the structure of final expenditure of households in the Visegrad Group member states. The Visegrad Group was established in 1991 as an association of three countries: Poland, Hungary and the then Czechoslovakia. Since 1993, as a result of the collapse of Czechoslovakia, the Visegrad Group has consisted of the following four countries: Poland, Hungary, the Czech Republic, and Slovakia. These countries have a similar history related to the transition from the command-order

\footnotetext{
* Corresponding author: Nicolaus Copernicus University, Faculty of Economic Sciences and Management, Gagarina 13a, 87-100 Toruń,m.jankiewicz@umk.pl
} 
economy to the market economy as well as to their dependence on the Soviet Union until the end of the 1980s. The association was established for the purpose of political and economic cooperation and was aimed at carrying out institutional reforms and bringing Western Europe closer to the countries. As a result of cooperation of the Visegrad Group countries, all countries started membership negotiations with the European Union in 1998 and in 2004 were admitted to the EU structures. Already in the first period of membership in 2005-2007, the Visegrad Group countries had the same number of votes in the Council of the European Union as France and Germany together (58 votes each). Undoubtedly, France and Germany have been setting the main tone of the European Union's internal development policy since 2004 (see: Balcerzak, 2015). Until 2016, the Visegrad Group countries had been focused primarily on institutional reforms to catch up with the old EU member states. After 2016, a slow socio-economic crisis began in the European Union, related to the problems of the inflow of a huge number of immigrants and the slowdown in the economic development of the member states. Since 2016, the Visegrad Group countries have become increasingly important in sketching the development of the European Union, in contrast to the old member states (including Germany and France), which, due to the worsening internal political situation, are holding back necessary institutional reforms in the EU. It appears that these are the countries of the Visegrad Group that will play a key role in the process of transforming the structure of the European Union in the coming years and will contribute to its improvement at the international level.

In the subject literature, the structure of consumption along with its determinants is a frequently considered topic (see: Grzega, 2015; Jankiewicz \& Pietrzak, 2019; Pietrzak \& Jankiewicz, 2019). Differences in consumption between European countries are most often considered and the disparities in the structure of consumption between the countries of the Eastern Bloc and the countries of the Western Bloc of the European Union are pointed out. It is emphasized that the countries of Central and Eastern Europe (including the Visegrad Group countries) are characterized by a less favourable structure of consumer spending (see: Dudek \& Koszela, 2013; Šoltés \& Nováková, 2016). A special case for Poland was considered in the work by Piekut (2013), where the conclusions show significant differences when compared to the structure of expenditure of Western European countries. In the literature, attention is drawn to the similarity between consumption structures in the Czech Republic, Hungary, Poland and Slovakia (see: Kuśmierczyk \& Piskiewicz, 2012), which justifies the consideration of this group of countries in the article. It should be emphasized, however, that research done on longer time periods indicates positive changes in the consumption structure of the New Union countries (including the Visegrad Group countries), despite the occurrence of significant differences, when compared to the Old Union countries (see: Piekut, 2015; Mikuła, 2017).

The authors' attention was focused on services and food expenditure. The evolution of these two categories of expenditure reflects the economic level and standard of living in each country. For this reason, the study focused on spending on these goods. Progressing globalization is the reason for the growing importance of services in every economy, whose size and level of development reflects the level of development of countries. Previous studies state that the highest share of services in generating GDP is recorded in well developed countries. The country's economic development also determines the amount of disposable income of households which also report the need to use services (see: Jankiewicz, 2018a). Households with a higher level of disposable income can afford more diverse consumption, including higher consumption of services than less affluent households. The enrichment of society contributes to changes in the structure of 
consumption, related to the possibility of consuming an increasing number of non-food goods. Therefore, the socio-economic situation of the country is one of the most important factors affecting the level of service consumption and the structure of household expenditure (see: Bilan, 2013; Simionescu et al., 2017; Kravčáková \& Kotulič, 2015; Fogarassy et al., 2018; Pietrzak \& Jankiewicz, 2019).

As part of satisfying the basic existential needs of man, households spend part of the money they earn on food. This fact states that food expenses are the most important part of their spending plan. However, as the disposable income of households increases, the share of food expenditure in the expenditure structure decreases, despite the increase in their level (according to Engel's law, see Horáková, 2015; Jankiewicz \& Pietrzak, 2019; Verba \& Kudinova, 2019). It is only when basic needs are met that households begin to think about satisfying higher-order goods also through the use of services. The literature draws attention to the positive impact of socio-economic development on the structure of household consumption structure in the Visegrad Group countries. The impact is understood as a decrease in the share of expenditure on food and non-alcoholic beverages (see: Utzig, 2015; Jankiewicz \& Pietrzak, 2019).

The research objective of the article is to analyse changes in the structure of expenditure on services and food goods in the Visegrad Group member states in the time period 1996-2016. The adopted period includes preparation in the Czech Republic, Hungary, Poland, and Slovakia for accession to the structures of the European Union, the moment of accession of the countries to the Community, the period of economic prosperity in 2005-2007 as part of membership in the structures of the European Union, and the time of the global financial crisis in the years 2008-2012. The years 2012-2016, in turn, represent the first period of functioning of the economies of the Visegrad Group countries after the global financial crisis. The year 1996 is assumed for postcommunist countries to be the moment of finalization of necessary reforms allowing the transition of these countries to market economies. The implementation of the goal allowed to assess the shaping of the structure of household expenditure in terms of determining development trends in both expenditure on services and food.

The choice of such a long period of analysis also allowed the determination for each of the four countries of the Visegrad Group the limit values of consumption shares of both components of the structure of household expenditure in final expenditure using a model based on the Törnquist function. The Törnquist model is one of the most popular models used to forecast and analyse changes in household consumption demand (see: Hanusik \& Langowska-Szczęśniak, 2017; Michorowski, 2017). The determined saturation levels allowed for a more complete assessment of potential changes in the structure of household expenditure in selected countries. The level of saturation is the maximum value of the share of expenditure on selected categories of goods that households can achieve with an infinite increase in their disposable income.

In the article, the authors formulated two research hypotheses. The first hypothesis assumes that with the development of the socio-economic level of the country, the difference between the share of expenditure on services and the share of expenditure on food increases over time. In the second hypothesis, it was assumed that from a certain point in time the difference between the shares of expenditure on services and food stabilizes, which is related to the approach of the countries to saturation levels. 


\section{DISPOSABLE INCOME OF HOUSEHOLDS FOR THE VISEGRAD GROUP COUNTRIES}

The empirical study focused on the analysis of changes in the share of expenditure on services and the share of expenditure on food in the structure of final expenditure of households in the Visegrad Group countries. Within the group of countries, household expenses in the Czech Republic, Hungary, Poland, and Slovakia for the time period 1996-2016 were considered. The data were obtained from the database of the European Statistical Centre. All of these countries in 1996 continued the transformation of the economy, which had been commenced in the early 1990s, from a centrally planned economy to a market economy. The systematic marketization of the economies allowed these countries to join the structures of the European Union in 2004. At the time of accession to the Community, these countries were characterized by differences in the level of socio-economic development, but all countries noted a positive impact of accession on the economic quality of life, which could be especially seen in Poland (Nowak, 2018; Miłek, 2018) and their international growth potential based on competitive advantages (Cheba \& SzopikDepczyńska, 2017; Balcerzak, 2016).

Literature research on the structure of consumption in European countries indicates various determinants affecting the shape of this structure. One of the main factors shaping the structure of consumer spending is household wealth, measured by the level of disposable income (see: Bretyn, 2013; Jankiewicz, 2018b). The categories of household expenditure selected by the authors in the form of expenditure on services and food are most dependent on the level of disposable income per capita. Therefore, the study began with an analysis of changes in disposable income of households. It should be emphasized that as a result of the transformation of the economies of selected post-communist countries and the process of economic convergence, there was a significant increase in the level of GDP per capita (see: Wójcik, 2017; Kuc; 2017). After the Visegrad countries have joined the EU structures, they can be described as a group of countries forming a convergence club, where the process of economic convergence takes place both within the club and throughout the EU. The systematic increase in the level of GDP per capita translates into an increase in the level of disposable income in households and a change in the structure of their expenditure. Table 1 presents the level of disposable income of households for the Czech Republic, Hungary, Poland and Slovakia in 1996, 2004, 2012, 2016 and its percentage changes in subsequent periods. Such a comparison allowed carrying out an analysis of changes in disposable income of households in the examined period. In 1996, the highest level of disposable income per capita was recorded in the Czech Republic (EUR 2871.24). In Hungary and Poland, the starting disposable income per capita was at a similar level (EUR 2213.39 and EUR 2354.35, respectively), and Slovakia had the lowest level (EUR 1111.77). In the years 1996-2004 the level of disposable income increased significantly, more than twice in the case of Hungary and Slovakia. In 2004, in the Czech Republic and Hungary, disposable income of households was at a similar level (EUR 5056.72 and EUR 5010.31), significantly exceeding the disposable income recorded in Poland and Slovakia (where the level of income was also similar, respectively EUR 3607.46 and 3896.78 EUR). After 2004, as part of belonging to the Community, there was an increase in the level of disposable income of households in the Czech Republic, Poland and Slovakia (to the level of EUR 8454.28, EUR 6252.61, EUR 8018.95, respectively). It should be emphasized that despite the occurrence of the global financial crisis, the level of disposable income of households for the Czech Republic, Poland, and Slovakia increased again significantly in 2004-2012. In the case of Hungary, the situation was different, where in the years 2004-2012 there was a low increase in the level of 
disposable income of households by $19.97 \%$ (income at the level of EUR 6011.02). It should be emphasized that in Hungary, when this country joined the EU, an economic crisis began, from which Hungary's economy began to recover only after 2012. In the period 2012-2016, when the Visegrad countries achieved a stable economic situation after the global financial crisis, the lowest increase in the level of disposable income of households was recorded. For Hungary, Poland and Slovakia, the increase in disposable income fluctuated around $10 \%$, and achieved $9.56 \%, 8.84 \%$ and $10.25 \%$, respectively (see Table 1). In the Czech Republic, the increase in disposable income reached the lowest level $(3.92 \%)$. In the context of the increase in disposable income throughout the entire period analysed (i.e., 1996-2016), it should be emphasized that the income growth was very low in 2012-2016.

Table 1: Disposable Income of Households for the Visegrad Group Countries

\begin{tabular}{lcccccccc}
\hline \multicolumn{1}{c}{ Country } & \multicolumn{4}{c}{ Disposable income p.c. } & \multicolumn{5}{c}{ Percentage change } \\
& $\mathbf{1 9 9 6}$ & $\mathbf{2 0 0 4}$ & $\mathbf{2 0 1 2}$ & $\mathbf{2 0 1 6}$ & $\mathbf{1 9 9 6}-$ & $\mathbf{2 0 0 4 -}$ & $\mathbf{2 0 1 2 -}$ & $\mathbf{1 9 9 6 -}$ \\
& & & & & $\mathbf{2 0 0 4}$ & $\mathbf{2 0 1 2}$ & $\mathbf{2 0 1 6}$ & $\mathbf{2 0 1 6}$ \\
\hline $\begin{array}{l}\text { Czech } \\
\text { Republic }\end{array}$ & 2871.235 & 5056.719 & 8454.283 & 8785.331 & $76.12 \%$ & $67.19 \%$ & $3.92 \%$ & $205.98 \%$ \\
Hungary & 2313.387 & 5010.309 & 6011.020 & 6585.433 & $116.58 \%$ & $19.97 \%$ & $9.56 \%$ & $184.67 \%$ \\
Poland & 2354.349 & 3607.458 & 6252.609 & 6805.083 & $53.23 \%$ & $73.32 \%$ & $8.84 \%$ & $189.04 \%$ \\
Slovakia & 1911.774 & 3896.777 & 8018.952 & 8840.909 & $103.83 \%$ & $105.78 \%$ & $10.25 \%$ & $362.45 \%$ \\
\hline \hline
\end{tabular}

Source: own calculation (disposable income per capita expressed in EURO is the total disposable income od households calculated as per capita)

Figure 1 shows the level of disposable income of households in the years 1996-2016 for each country. The visual analysis of Figure 1 carried out confirms earlier conclusions about the dynamic upward trend of disposable income over the period considered. The changes observed in the level of disposable income of households are largely associated with the increase in the level of socio-economic development of the countries surveyed, though it should be remembered that its distribution can be also affected by many non-economic factors (see: Landmesser, 2019; Verba \& Kudinova, 2019; Malkina, 2019; Kompa \& Witkowska, 2018; Tvaronavičienè \& Gatautis, 2017). Both in the period before accession to the European Union and after accession to the Community, the Visegrad Group countries significantly improved the situation of their economies as a result of numerous institutional reforms (see: Balcerzak, 2020; Bilan et al., 2017). Figure 1 also shows the different nature of the upward trend in disposable income per capita for each country. In the case of the Czech Republic, Hungary and Slovakia, a slowdown in the growth of disposable income of households is visible. However, in the case of Poland, the possibility of continuing the upward trend for disposable income is observed. 
Figure 1: The Dynamics of Disposable Income of Households
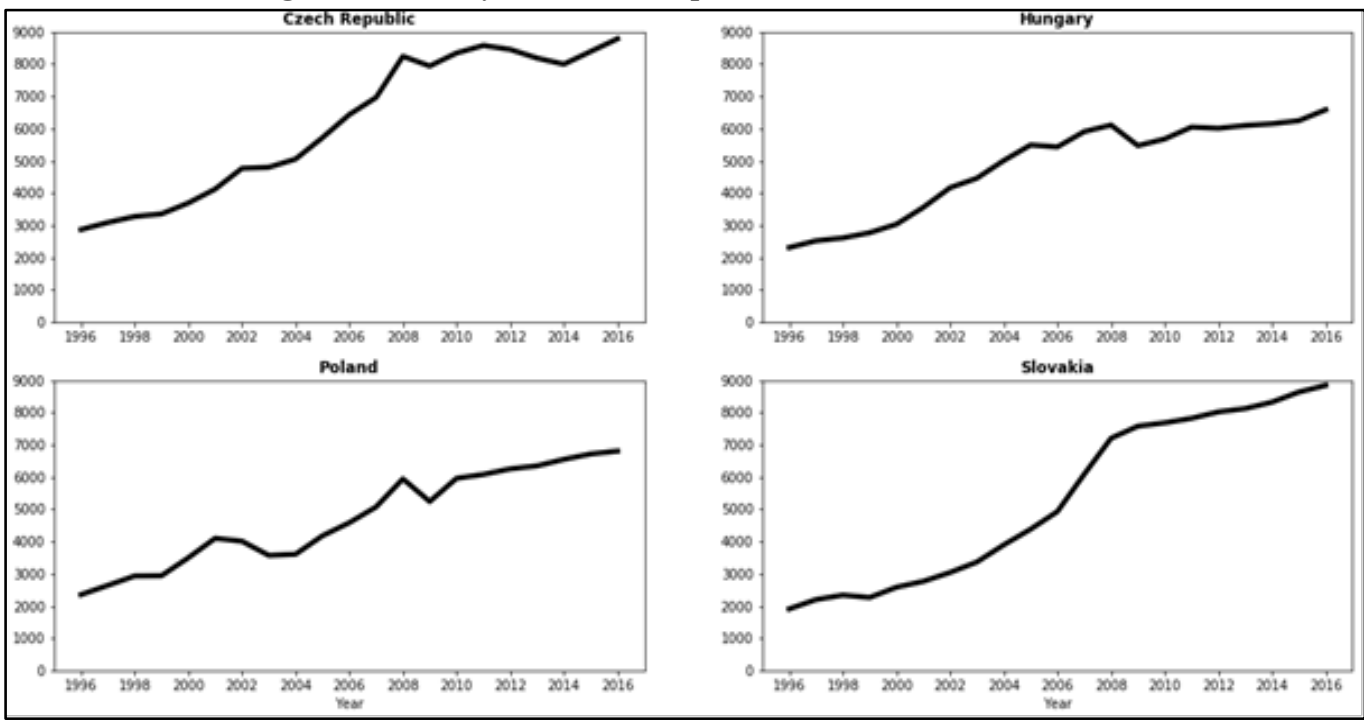

Source: own elaboration

Summing up the analysis conducted, it should be emphasised that in the period 1996-2016 there were significant changes in the level of disposable income of households of the countries examined. The analysis of disposable income changes over the period under review confirms the diversity in the level of development of the economies of the Visegrad Group countries (see: Balcerzak, 2015). Although the Czech Republic and Slovakia achieved a similar level of disposable income in 2012 and 2016, both in 1996 and 2004, the countries were characterized by significant differences in the level of socio-economic development in favour of the Czech Republic. The economic development of Hungary and Poland was completely different, and the two countries achieved a similar level of disposable income in 2012 and 2016, however Poland noted a higher level. It should be noted that among the countries of the Visegrad Group, the Czech and Polish economies in 2016 were characterized by a higher institutional level compared to Hungary and Slovakia (see also Balcerzak, 2015; 2020).

\section{ANALYSIS OF CHANGES IN THE SHARE OF EXPENDITURE ON SERVICES AND FOOD IN THE VISEGRAD GROUP MEMBER STATES}

The changes observed in the level of disposable income have undoubtedly translated into changes in household expenditure on services and food, which is an argument in the context of further analysis of changes in the structure of expenditure. Expenditure on services, which are an important element in the functioning of a modern economy, was analysed first. The share of the value of services in GDP currently shows the level of development of individual economies, where highly developed countries are characterized by the highest share of services (see: Piekut 2013). There is also feedback, where the level of socio-economic development of the country becomes a key determinant of the increase in the share of services in final expenditure of households (see: Kuśmierczyk \& Piskiewicz, 2012; Mikuła, 2017; Szwacka-Mokrzycka, 2018). However, within 
this issue one should also remember about the problem of proper measuring of socio-economic conditions, which can affect the design of efficient economic policies for improving the socioeconomic conditions that are crucial for the Visegrad countries (Ivanová \& Masárová, 2018).

The increase in the level of disposable income determined in the survey, as well as the improving socio-economic situation of the Visegrad Group countries, should contribute to an increase in the share of household expenditure on services. It should also be emphasized that the accession of the surveyed countries to the EU structures resulted in the takeover by consumption countries of the consumption patterns from highly developed countries, which also contributed to changes in the structure of final expenditure of households (see: Jankiewicz, 2018c). This means that the increase in disposable income is an important, but not the only determinant of changes in the share of expenditure on services. Changes in the share of expenditure on services are also associated with the systemic transformation of the economies of the Visegrad Group countries, in particular institutional changes, the involvement of foreign direct investment, an increase in the level of innovation in the economies, a change in consumption patterns, or with these countries belonging to international structures. An important factor is also the improvement of the labour market of the surveyed countries, which is a factor supporting the enrichment of households and the adoption of new consumption patterns (see Sadowska \& Dąbrowska, 2018; Dmytrów \& Bieszk-Stolorz, 2019).

Table 2 presents the development of the share of expenditure on services in the final expenditure of households for the countries surveyed in the period 1996-2016. In 1996, the highest and similar level of expenditure on services was recorded in the Czech Republic and Hungary (38.3\% and $38.2 \%)$. A lower level of the share of expenditure on services was in Slovakia $(35 \%)$ and Poland (32.9\%). In the period 1996-2004, the percentage change in the share of expenditure on services exceeded $20 \%$ only in the case of Poland, and was lower in other countries. The lowest increase in the share of expenditure on services was observed in Hungary (6.34\%), which indicates the weakness of the country's market transformation process. After the accession of these countries to the EU, in the period 2004-2012 a slight decrease in the share of expenditure on services in Poland and Slovakia was recorded $(0.42 \%$ and $0.28 \%)$. The Czech Republic also recorded a weak increase in the share of expenditure on services in this period (3.48\%). Hungary saw the largest increase in the share of expenditure (6.34\%), which was related to the occurrence of the economic crisis in this country and numerous reforms related necessitated by and it improving the structure of the economy. In the years 2012-2016 the situation in some countries changed. Hungary and Slovakia recorded a $2 \%$ increase in the share of expenditure on services $(2.53 \%$ and $2.14 \%$, respectively). In the case of the share of expenditure on services in the Czech Republic, it remained almost unchanged $(-0.08 \%)$. However, in this period Poland saw a decrease of $2.03 \%$ in the share of expenditure on services.

It should be noted that in the period 1996-2012 the share of expenditure on services increased in all countries, and the level of these shares in the years 2004, 2012 and 2016 were similar for a pair of the Czech Republic and Hungary (around 44\%) and for a pair of Poland and Slovakia (around $40 \%$ ). Also, the subject literature indicates in the case of the level of consumption of services in the Visegrad Group countries, the most favourable situation of the Czech Republic compared to other European Union countries and the least favourable situation of Poland (see: Włodarczyk, 2016). 
Table 2: The Share of Expenditure on Services for Visegrad Group Countries

\begin{tabular}{ccccccccc}
\hline \multirow{2}{*}{ Country } & \multicolumn{4}{c}{ Share of the services expenditures } & \multicolumn{4}{c}{ Percentage change } \\
& $\mathbf{1 9 9 6}$ & $\mathbf{2 0 0 4}$ & $\mathbf{2 0 1 2}$ & $\mathbf{2 0 1 6}$ & $\mathbf{1 9 9 6 - 2 0 0 4}$ & $\mathbf{2 0 0 4 - 2 0 1 2}$ & $\mathbf{2 0 1 2 - 2 0 1 6}$ & $\mathbf{1 9 9 6 - 2 0 1 6}$ \\
\hline Czech Republic & 0.3829 & 0.4338 & 0.4489 & 0.4485 & $13.28 \%$ & $3.48 \%$ & $-0.08 \%$ & $17.13 \%$ \\
Hungary & 0.3817 & 0.4059 & 0.4316 & 0.4425 & $6.34 \%$ & $6.34 \%$ & $2.53 \%$ & $15.95 \%$ \\
Poland & 0.3290 & 0.4053 & 0.4036 & 0.3954 & $23.19 \%$ & $-0.42 \%$ & $-2.03 \%$ & $20.19 \%$ \\
Slovakia & 0.3505 & 0.4069 & 0.4058 & 0.4145 & $16.11 \%$ & $-0.28 \%$ & $2.14 \%$ & $18.25 \%$ \\
\hline \hline
\end{tabular}

Source: own calculation

Then, household food expenditure was analysed. These expenses are also an important element of final expenses, because they meet the basic existential needs of households. Along with the increase in disposable income of households, the value of expenditure on food increases, however its share in the structure of final expenditure decreases (see: Jankiewicz, 2018b; Jankieiwcz 2019). After satisfying basic nutritional needs, households allocate increasing amounts to the purchase of non-food goods (see: Jankiewicz, 2018c). In addition, as the level of disposable income increases, households can spend more of it on savings (see: Kusairi et al., 2019; Trębska, 2018). Therefore, with the increase in the level of socio-economic development of the Visegrad Group countries, including institutional and structural changes in these economies, opposite changes should be expected for the share of expenditure on food compared to the trend in the share of expenditure on services.

Table 3 presents the share of expenditure on food in final expenditure of households for the Visegrad Group countries in the examined period. In 1996, the lowest share of food expenditure was recorded in the Czech Republic (18.4\%) and followed by Hungary (21.9\%). Undoubtedly, this was associated with a higher level of disposable income per capita in these countries in 1996 and a better economic situation, if compared to Poland and Slovakia. In Poland and Slovakia, a higher share of food expenditure was recorded in 1996 (28.2\% and 25.7\% respectively). In the period 1996-2004 there was a significant reduction in the level of food expenditure in all of the countries studied, exceeding 20\% for Hungary, Poland and Slovakia (22.0\%, 25.21\% and 25.63\% respectively). This is undoubtedly associated with the successful transformation of the economies of the countries under study, which resulted in a significant improvement in their economic situation. In the case of the Czech Republic, the lowest decrease in the share of food expenditure at the level of $15.01 \%$ was recorded in 1996-2004, which could be related to the fact that this country was getting closer to the saturation level (see Figure 6). It should be noted, however, that in 2004 the level of share of expenditure on food decreased, but again the lowest level was recorded by the Czech Republic and was followed by Hungary, Slovakia and Poland. In the period 20042012, there were significant differences in the level of changes in the share of food expenditure in individual countries. The smallest changes occurred in the case of the Czech Republic and Hungary, with the Czech Republic decreasing its share by $1.35 \%$ and the Hungarian share increasing by $1.64 \%$. The increase in the share of food expenditure in Hungary resulted from the country's active anti-crisis policy. The largest decreases in shares were recorded for Slovakia and Poland $(8.96 \%$ and $14.98 \%$, respectively), which should be treated as a natural consequence of the socio-economic development of these countries within the structures of the European Union. In 2012, the Czech Republic had the lowest level of food expenditure (15.4\%). Other countries were 
characterized by a higher and similar level of food expenditure (Hungary 17.4\%, Poland 17.9\% and Slovakia 17.4\%). In the years 2012-2016, that is in the period of economic calming down after the global financial crisis, the share of expenditure on food increased in the case of the Czech Republic, Hungary and Slovakia (respectively 4.07\%, 2.59\% and 2.06\%). This situation most likely resulted from a change in the attitude of society, from an attitude focused on savings to a consumer attitude. However, in the case of Poland, similar to the years 1996-2012, there was a systematic decrease in the share of expenditure on food, where in 2012-2016 a decrease of 4.65\% was recorded. Finally, in 2016, a similar level of share of expenditure on food was observed in Hungary, Poland and Slovakia (respectively 17.83\%, 17.10\% and 17.77\%). The Czech Republic recorded the lowest share of food expenditure in 2016 which amounted to $16.05 \%$.

Changes in the structure of consumption towards a decrease in the share of food expenditure in final expenditure resulted in all countries of the Visegrad Group from the improvement in the macroeconomic situation of the countries (see: Gavurova et al., 2016; 2017). Similarly, in the literature it is indicated that in the group of Visegrad Group countries the Czech Republic has a consumption structure (including the level of food expenditure share) most similar to that of the Old Union countries, while Poland was recognized as a country with the most distant consumption structure (see: Liobikienè \& Mandravickaitè, 2013).

Table 3: Share of Household Expenditure on Food

\begin{tabular}{lcccccccc}
\hline \multirow{2}{*}{ Country } & \multicolumn{3}{c}{ Share of the food expenditures } & \multicolumn{4}{c}{ Percentage change } \\
& $\mathbf{1 9 9 6}$ & $\mathbf{2 0 0 4}$ & $\mathbf{2 0 1 2}$ & $\mathbf{2 0 1 6}$ & $\mathbf{1 9 9 6 - 2 0 0 4}$ & $\mathbf{2 0 0 4 - 2 0 1 2}$ & $\mathbf{2 0 1 2 - 2 0 1 6}$ & $\mathbf{1 9 9 6 - 2 0 1 6}$ \\
\hline Czech Republic & 0.1840 & 0.1564 & 0.1543 & 0.1605 & $-15.01 \%$ & $-1.35 \%$ & $4.07 \%$ & $-12.74 \%$ \\
Hungary & 0.2192 & 0.1710 & 0.1738 & 0.1783 & $-22.00 \%$ & $1.64 \%$ & $2.59 \%$ & $-18.66 \%$ \\
Poland & 0.2821 & 0.2110 & 0.1794 & 0.1710 & $-25.21 \%$ & $-14.98 \%$ & $-4.65 \%$ & $-39.37 \%$ \\
Slovakia & 0.2571 & 0.1912 & 0.1741 & 0.1777 & $-25.63 \%$ & $-8.96 \%$ & $2.06 \%$ & $-30.91 \%$ \\
\hline \hline
\end{tabular}

Source: own calculation

The literature also touches on the topic of the similarity of household consumption structures in European countries, where the progress of the convergence of structures was discussed in the works of Bretyn (2013), Grzega (2015), Jankiewicz (2018a, 2018c, 2019), Liobikienè \& Juknys (2012), Mikuła (2017) and Szwacka-Mokrzycka (2018). The ongoing process of economic convergence between countries causes, among other things, the unification of disposable income of households, which translates into systematic changes in the level and structure of consumption in less developed countries, when compared to wealthy countries. These changes concern the increase in the share of expenditure on services at the expense of the share of expenditure on food. The literature indicates the existence of consumerism in the member states of the European Union, which undoubtedly contributes to the takeover of consumption patterns by households of poorer countries. The harmonization of consumption patterns also intensifies the desire to imitate households in wealthy countries by less-wealthy households. 
Figure 2: Comparison of the Dynamics of Share of Expenditure on Services and Food
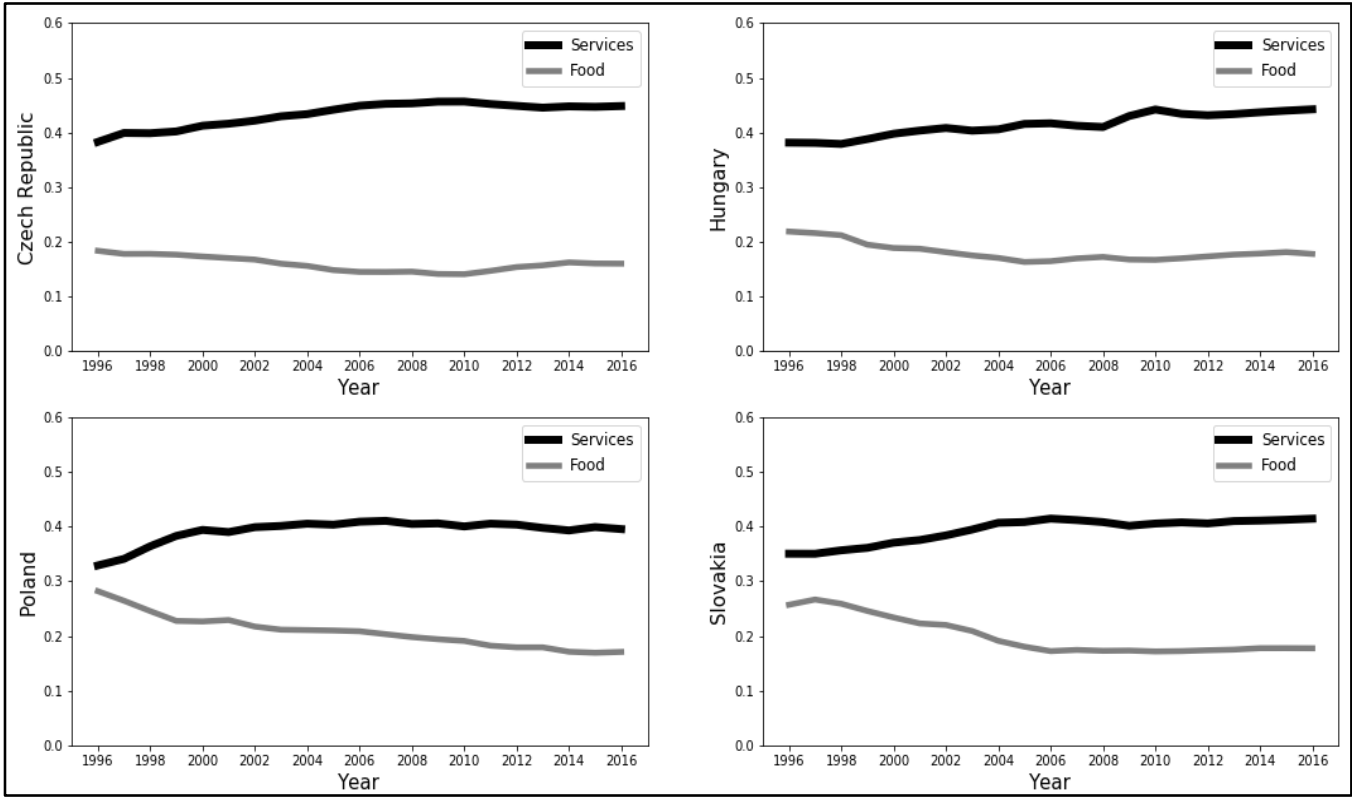

Source: own elaboration

Figure 3: The Difference in Percentage Points of the Share of Expenditure on Services and Food
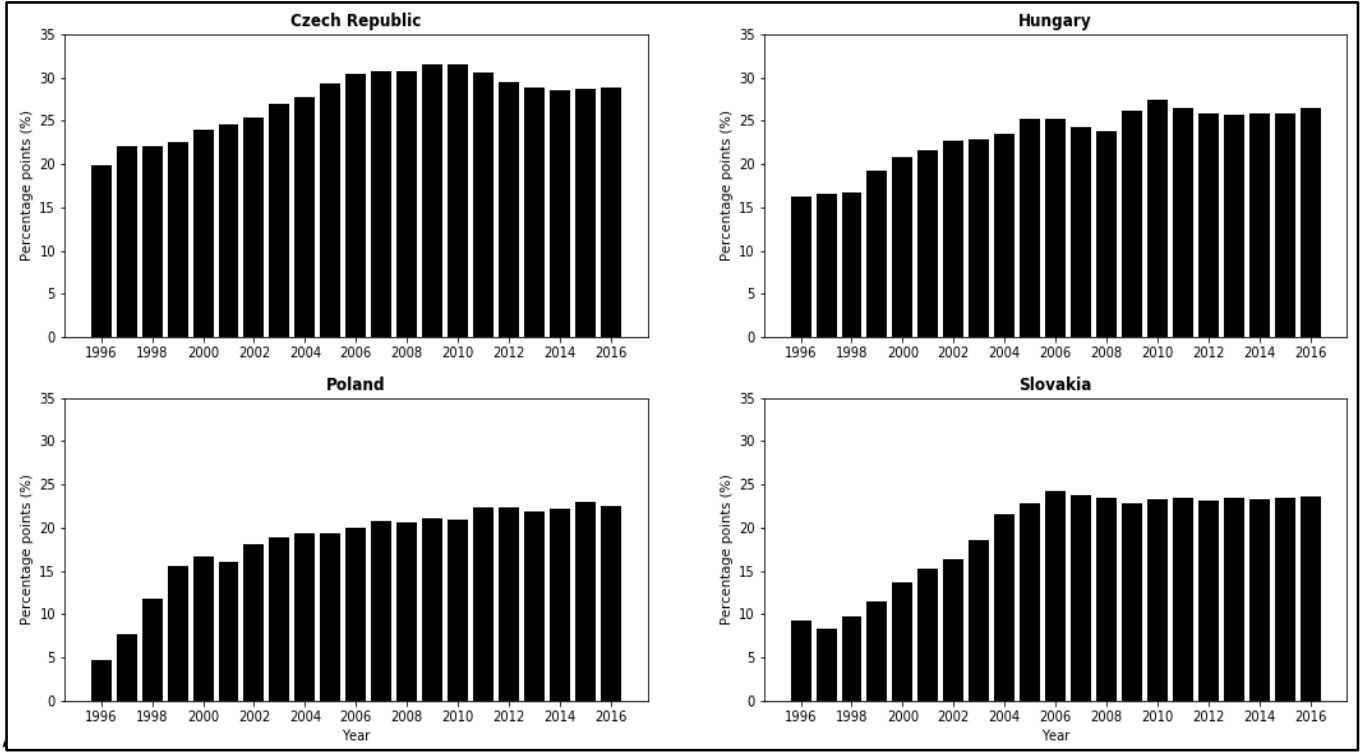

Figure 2 shows, for each of the surveyed countries, the share of expenditure on services and food expenditure in 1996-2016. Figure 3 shows the difference in percentage points of the share of 
expenditure on services and expenditure on food in each country. In the study period considered, there is an upward trend in the share of expenditure on services and a downward trend in the share of expenditure on food. Visual assessment of Figure 2 and Figure 3 indicates the process of converging consumption structures in the Visegrad Group countries. Moreover, it should be noted that from 1996 to 2016 the difference between the share of expenditure on services and the share of expenditure on food increased significantly. Undoubtedly, the main determinant of the growing difference between the shares was the increase in the level of disposable income per capita in all of the countries studied in the period 1996-2016 (see Figure 1 and Table 1), which confirms the authors' first research hypothesis.

It should be emphasized, however, that in Figures 2 and 3 a different character of development trends is visible for each country in the years 1996-2016. This is a consequence of different levels of advancement of the economic development of countries (see: Cheba, 2015; Cheba \& SzopikDepczyńska, 2017; Simionescu et al., 2017; Szopik-Depczyńska et al., 2017; 2018b; Dmytrów \& Bieszk-Stolorz, 2019; Skare \& Porada-Rochoń, 2019a; 2019b; Kuc-Czarnecka et al., 2020), including the level of institutional development (see: Balcerzak, 2020), internationalization of these countries (see: Pietrzak \& Lapińska, 2015; Łapinska, 2016; Kurowska-Pysz et al., 2018; Jaklič \& Svetličič, 2019; Sánchez-López et al., 2019; Shkolnyk et al., 2019), degree of innovation (see: Szopik-Depczyńska et al., 2018a; Jakimowicz \& Rzeczkowski, 2019) or the level of digital economy (see: Balcerzak, 2017; Balcerzak \& Pietrzak, 2017; Pietrzak \& Ziemkiewicz, 2018a; 2018b; 2019; Victor et al., 2019).

In 1996, the difference between the share of expenditure on services and food is much higher in the case of the Czech Republic and Hungary, when compared to Poland and Slovakia. This fact corresponds to the initial level of disposable income per capita, which in 1996 was much higher for the first pair of countries (see Table 1). The size of the difference between the shares in 1996 is crucial because the upward trend in the share of expenditure on services and the downward trend in the share of expenditure on food are much stronger in the case of Poland and Slovakia. The identified development trends in the shaping of the share of household expenditure are characterized by the highest intensity in the time period 1996-2005, and then they slowed down from 2006 on for all countries (see Figure 2). It should be emphasized that after 2006 there were individual changes in the share of expenditure, but it seems that the slowdown in development trends is of a lasting nature. Much larger fluctuations occurred in Hungary and Slovakia, however, in the case of these countries it can be stated that from 2005 on the difference between the share of expenditure on services and on food was at a similar level. The established results constitute an argument for the second research hypothesis stating the stabilization of the difference between the expenditure shares of both goods, which is related to the approach of the countries to saturation levels.

\section{THE LIMIT VALUES FOR THE SHARE OF EXPENDITURE ON SERVICES AND FOOD EXPENDITURE}

In connection with the analysis of changes in the shaping of expenditure on services and food expenditure, the article also attempts to determine the limit values of the shares concerned. The limit values set for individual countries should be treated as the benchmark saturation level for the share of expenditure on selected types of goods towards which households are heading and which, 
with the current trend of changes, are able to achieve in the future (see: Zalega, 2013). The limit values were determined on the basis of the Törnquist model (see: Pawłowski, 1980; Zalega, 2011):

$$
Y_{t}=\frac{\alpha_{0} \cdot X_{t}}{X_{t}+\alpha_{1}}+\varepsilon_{t}
$$

where $Y_{t}$ is share of expenditure on services or food, $X_{t}$ is disposable income of households, $\alpha_{0}$ is a parameter of saturation level, $\alpha_{1}$ indicates the nature of good, and $\varepsilon_{\mathrm{t}}$ is a random component.

For the estimation process we need the non-linear form of the equation (1):

$$
Z_{1 t}=\beta_{0}+\beta_{1} Z_{0 t}+\eta_{t}
$$

where: $Z_{1 \mathrm{t}}=\frac{1}{Y_{\mathrm{t}}}$ is independent variable, $\beta_{0}=\frac{1}{\alpha_{0}}, \beta_{1}=\frac{\alpha_{1}}{\alpha_{0}}$ are parameters of the model and $\eta_{t}$ is a random component.

First, saturation levels were determined for the share of expenditure on services in final expenditure of households. In the first step of the estimation procedure, the parameters of the auxiliary model determined by equation (2) were estimated for the Czech Republic, Hungary, Poland, and Slovakia. The model specification assumes the share of expenditure on services in individual countries as variable $Y_{t}$, and the level of disposable income of households per capita as variable $X_{t}$. In the next step of the study, based on the obtained parameter ratings $\beta_{0}, \beta_{1}$, the ratings of structural parameters $\alpha_{0}$ and $\alpha_{1}$ were calculated for the model determined by equation (1). The obtained results are presented in Table 4 , where for each of the models the structural parameters $\beta_{0}$ and $\beta_{1}$ are statistically significant and the models are characterized by a high degree of matching to empirical data. Table 4 also shows the calculated assessments of parameters $\alpha_{0}$ and $\alpha_{1}$. The assessments of individual parameters $\alpha_{0}$ show the saturation level for the share of expenditure on services in individual countries. In turn, positive evaluations of the parameter $\alpha_{1}$ received for all countries surveyed confirm the nature of services as a higher-order good.

\begin{tabular}{|c|c|c|c|c|c|}
\hline \multicolumn{3}{|c|}{ Czech Republic } & \multicolumn{3}{|c|}{ Hungary } \\
\hline Parameter & Estimate & p-value & Parameter & Estimate & p-value \\
\hline$\beta_{0}$ & 2.019 & $\sim 0.00$ & $\beta_{0}$ & 2.137 & $\sim 0.00$ \\
\hline$\beta_{1}$ & 1568.830 & $\sim 0.00$ & $\beta_{1}$ & 1221.690 & $\sim 0.00$ \\
\hline$R^{2}$ & \multicolumn{2}{|c|}{0.960} & $R^{2}$ & \multicolumn{2}{|c|}{0.813} \\
\hline$\alpha_{0}$ & 0.500 & - & $\alpha_{0}$ & 0.470 & - \\
\hline$\alpha_{1}$ & 777.083 & - & $\alpha_{1}$ & 571.653 & - \\
\hline \multicolumn{3}{|c|}{ Poland } & \multicolumn{3}{|c|}{ Slovakia } \\
\hline Parameter & Estimate & p-value & Parameter & Estimate & p-value \\
\hline$\beta_{0}$ & 2.204 & $\sim 0.00$ & $\beta_{0}$ & 2.284 & $\sim 0.00$ \\
\hline$\beta_{1}$ & 1510.160 & $\sim 0.00$ & $\beta_{1}$ & 1074.09 & $\sim 0.00$ \\
\hline$R^{2}$ & \multicolumn{2}{|c|}{0.623} & $R^{2}$ & \multicolumn{2}{|c|}{0.891} \\
\hline$\alpha_{0}$ & 0.454 & - & $\alpha_{0}$ & 0.438 & - \\
\hline$\alpha_{1}$ & 685.271 & - & $\alpha_{1}$ & 470.170 & - \\
\hline
\end{tabular}

Table 4: Results of Estimation of the Törnquist Model for the Share of Expenditure on Services

Source: own calculation 
Figure 4: Real and Theoretical Values Obtained from the Törnquist Model for Service Expenditure Shares

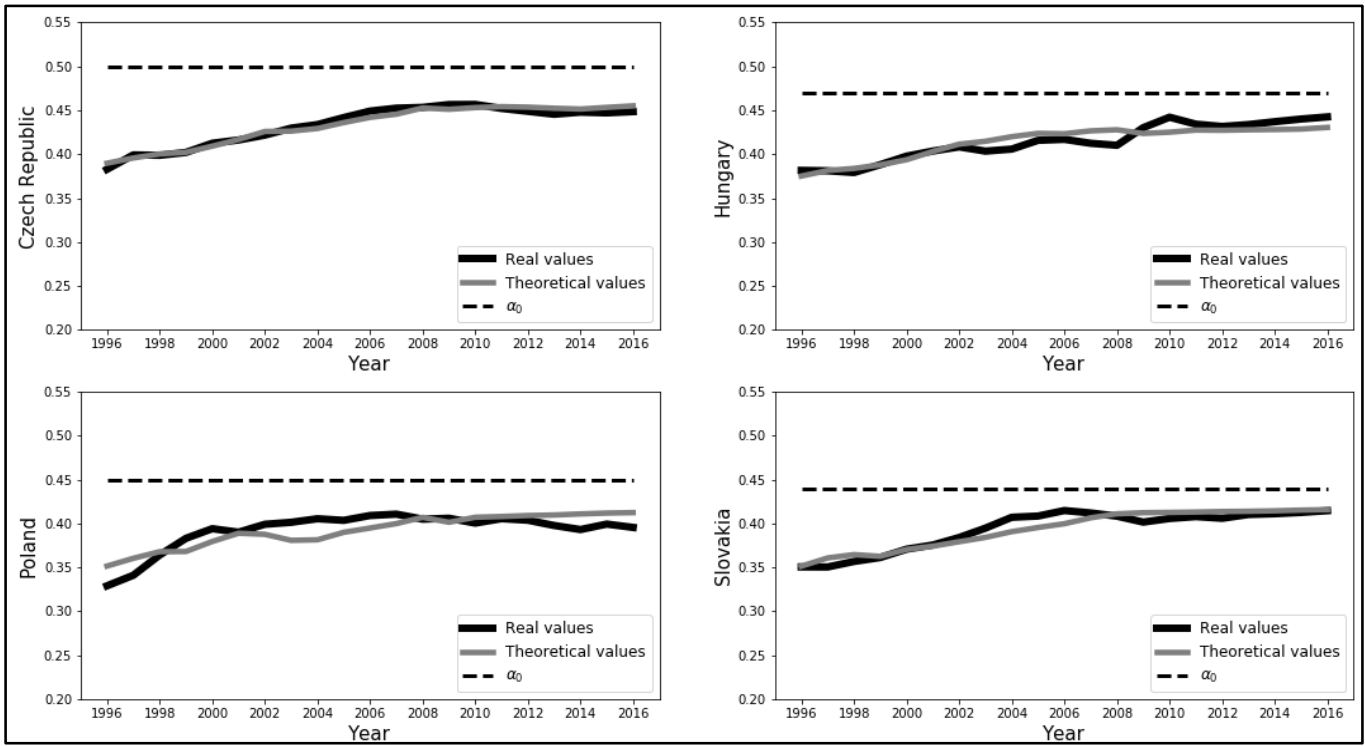

Source: own elaboration

Figure 4 presents the theoretical values of the estimated Törnquist models and empirical values in the form of actual values of the share of expenditure on services in the consumption structure for each country separately. Visual assessment of the presented values allows to state high compliance of theoretical values with empirical values for all models. In addition, for each country, saturation levels for the share of expenditure on services are marked with dashed lines in accordance with the received assessments of parameters $\alpha_{0}$ (see Table 4). The highest saturation level was recorded for the Czech Republic (50\%). In the case of Hungary, the saturation level was 47\%, and for Poland and Slovakia the saturation levels were $45.4 \%$ and $43.8 \%$ respectively. Despite the fact that Hungary and Slovakia had saturation levels at a lower level when compared to the Czech Republic and Hungary, the share of expenditure on services in these countries in 2016 was much closer to the saturation level. This means that in case of significant socio-economic development, there is less likelihood of an increase in the share of expenditure on services in Poland and Slovakia than in the cases of the Czech Republic and Hungary.

Then saturation levels were determined for the share of food expenditure in final household expenditure for the countries studied. Also in this case, the level of saturation is understood as the share of expenditure on food goods that households can achieve, taking into account its current tendency to change. In accordance with the adopted methodology, a two-stage estimation procedure was used, where in the first step the parameters $\beta_{0}, \beta_{1}$ of the auxiliary model were estimated, and in the second step the evaluation of the parameters $\alpha_{0}$ and $\alpha_{1}$ of the Törnquist type I model was determined. The results obtained for both models are presented in Table 5. For all models, the statistical significance of the structural parameters $\beta_{0}$ and $\beta_{1}$ was found, as well as their high degree of matching with empirical data. The determined parameter estimates $\alpha_{1}$ have negative signs, which confirms the nature of food in household expenditure of the Visegrad Group 
countries as a basic good. Table 5 also shows the values of parameter ratings $\alpha_{0}$ which indicate the level of saturation for the share of food expenditure in individual countries.

Table 5: The Estimation Results of the Törnquist Model for the Share of Food Expenditure

\begin{tabular}{cccccc}
\hline \hline & Czech Republic & & & Hungary \\
Earameter & Estimate & p-value & Parameter & p-value \\
\hline$\beta_{0}$ & 7.317 & $\sim 0.00$ & $\beta_{0}$ & 6.591 & $\sim 0.00$ \\
$\beta_{1}$ & -5423.930 & $\sim 0.00$ & $\beta_{1}$ & -4512.420 & $\sim 0.00$ \\
$R^{2}$ & 0.683 & & $R^{2}$ & 0.814 & \\
$\alpha_{0}$ & 0.137 & - & $\alpha_{0}$ & 0.152 & - \\
$\alpha_{1}$ & -741.260 & - & $\alpha_{1}$ & -684.585 & - \\
\hline \multicolumn{7}{c}{ Parameter } & Poland & & & Slovakia & \\
$\beta_{0}$ & Estimate & $\mathbf{p}$-value & Parameter & Estimate & p-value \\
$\beta_{1}$ & 6.680 & $\sim 0.00$ & $\beta_{0}$ & 6.471 & $\sim 0.00$ \\
$R^{2}$ & -7611.680 & $\sim 0.00$ & $\beta_{1}$ & -5476.330 & $\sim 0.00$ \\
$\alpha_{0}$ & 0.884 & & $R^{2}$ & 0.939 & \\
$\alpha_{1}$ & 0.150 & - & $\alpha_{0}$ & 0.155 & - \\
\hline \hline
\end{tabular}

Source: own calculation

Figure 5: Actual and Theoretical Values Obtained From the Törnquist Model for Food Expenditure shares

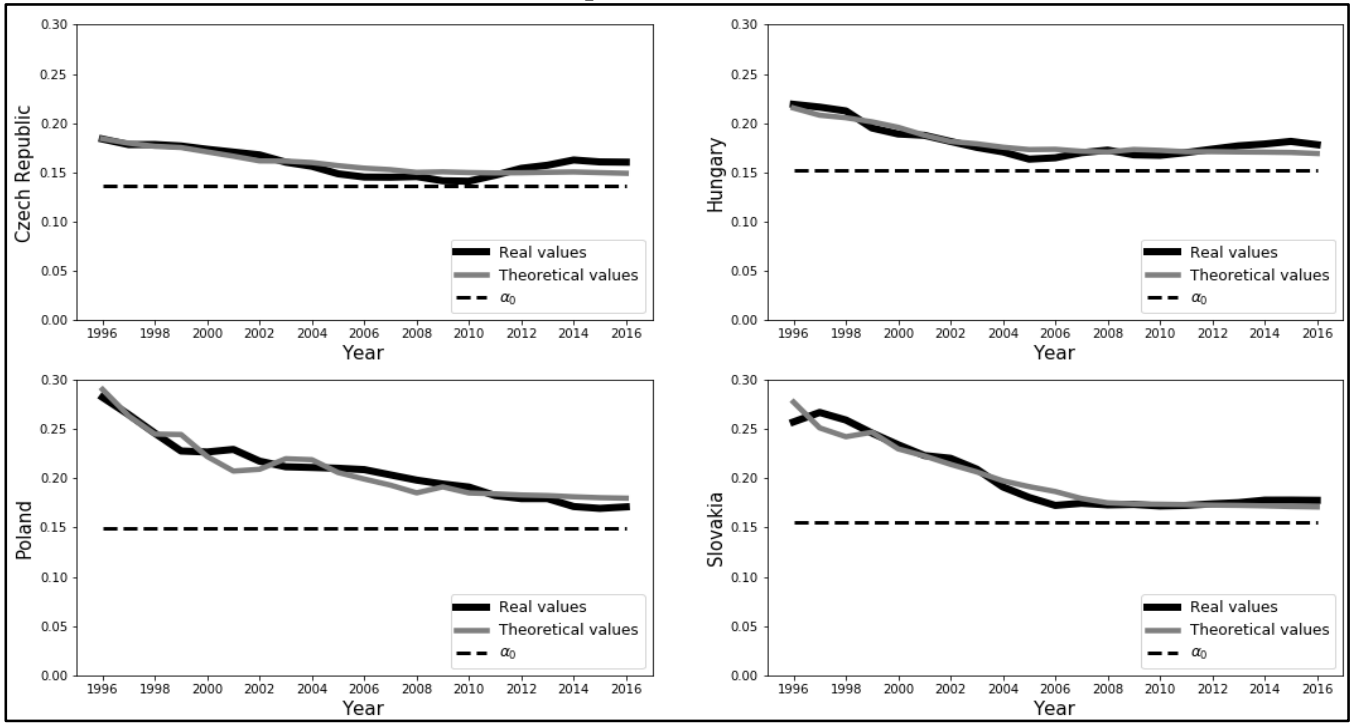

Source: own elaboration

Also in the case of the considered expenditure of food expenditure, the results of the Törnquist model estimation are presented in Figure 6. The visual analysis of Figure 5 indicates again a high 
compliance of theoretical values obtained from the model with the empirical values of food expenditure for each country separately. Similarly to Figure 4, saturation levels for food expenditure shares were marked with a dashed line (see Table 5). The highest saturation level was recorded for Slovaka (15.5\%). Then, comparable saturation levels were obtained for Hungary and Poland, $15.2 \%$ and $15 \%$ respectively. The Czech Republic saw the lowest saturation level (13.7\%). For the share of food expenditure, the Czech Republic was closest to saturation in 2016. In 2016, the distance of the shares of food from saturation levels for Slovakia, Hungary, Poland were at a similar level.

\section{CONCLUSION}

The article analyses the changes in the share of expenditure on services and the share of expenditure on food for households in the Czech Republic, Hungary, Poland and Slovakia in the years 1996-2016. The study began with an analysis of the level of disposable income, which is the main factor influencing the structure of consumer spending. Then, an assessment was made of the share of expenditure on services and food expenditure. For each of the Visegrad Group countries, a dynamic increase in disposable income per capita was established in the adopted study period, which resulted from the systematic increase in the level of socio-economic development of these countries (see: Simionescu et al., 2018) and growing effectiveness of their labour markets (Rollnik-Sadowska \& Dąbrowska, 2018).. In all of the countries examined there was an upward trend in the share of expenditure on services and a downward trend in the share of expenditure on food. The identified development trends in the structure of household consumption indicate a significant improvement in the situation of the economies of the examined post-communist countries, which in 1996 were in the process of systemic transformation, and in subsequent years introduced institutional changes related to joining the structures of the European Union. This means that selected countries are not only economically similar to the so-called old European Union countries, but also show similarity in the area of household consumption patterns.

The study carried out showed similar trends in changes in consumption structures in the Visegrad Group countries, where the difference between the share of expenditure on services and the share of expenditure on food was growing in 1996-2016. Undoubtedly, changes in the structure of household consumption resulted from the socio-economic development of the Visegrad Group countries in the period under consideration. This indicates a significant link between macroeconomic indicators and the level of household consumption for selected types of goods. As a result of the analysis, it was also found that in the examined countries the development tendency started to slow down, both in the share of expenditure on services and in the share of expenditure on food. It was also found that in 2016 the difference between the shares of expenditure on services and food stabilized for all countries surveyed, which was related to the approach of saturation levels. However, it should be emphasised that the level of changes in the share of expenditure on services and food expenditure is different for individual countries.

Using the Törnquist model, the individual limit values (pattern) for the share of expenditure on services and food expenditure in household final expenditure were also determined for each country. In the countries surveyed, there should be a long-term approximation of the share of consumption expenditure or services to their individual patterns. It should also be assumed that the shares for selected countries may approach the maximum value of the standard among the 
examined group of countries in the case of services, or the minimum value of the standard in the case of consumption. This means that the countries of the Visegrad Group should monitor whether the structure of the share of expenditure on food and services is on an appropriate development path. Depending on the current situation, the countries should introduce institutional solutions and take measures to support or limit consumption trends for relevant goods.

In the case of expenditure on services, the level of saturation for the shares ranged from $43.8 \%$ to $50 \%$. The highest saturation level was recorded in the Czech Republic and the lowest in Slovakia. However, for food expenditure shares, the limit value ranged from $13.7 \%$ to $15.5 \%$. In this case, the Czech Republic had the lowest saturation level and Slovakia the highest. The study showed that the Slovakia, Hungary and Poland in 2016 were much further away from the saturation level compared to Czech Republic. This means that, in order to further increase the share of expenditure on services, Slovakia, Hungary and Poland should adopt system solutions to improve the functioning of economies.

\section{REFERENCES}

Balcerzak, A. P. (2015). Europe 2020 strategy and structural diversity between old and new member states. Application of zero-unitarization method for dynamic analysis in the years 2004-2013. Economics \& Sociology, 8(2), 190-210.

Balcerzak, A. P. (2016). Technological potential of European economy. Proposition of measurement with application of multiple criteria decision analysis. Montenegrin Journal of Economics, 12(3), 7-17.

Balcerzak, A. P. (2017). Digital economy in Czech Republic, Slovakia and Hungary. Measurement with TOPSIS based on entropy measure for objective weighting. In T. Loster \& T. Pavelka (Eds.), The 11th International Days of Statistics and Economics. Conference Proceedings (pp. 49-57). Prague: Libuse Macakova, Melandrium.

Balcerzak, A. P. (2020). Quality of institutions in the European Union countries. Application of TOPSIS based on entropy measure for objective weighting. Acta Polytechnica Hungarica, 17(1), 101-122.

Balcerzak, A. P., \& Pietrzak, M. B. (2017). Digital Economy in Visegrad Coutnries. Multiplecriteria decision analysis at Regional Level in the Years 2012 and 2015. Journal of Competitiveness, 9(2), 5-18.

Bilan, Y. (2013). Sustainable development of a company: Building of new level relationship with the consumers of XXI century. Amfiteatru Economic Journal, 15(7), 687-701.

Bilan, Y., Gavurova, B., Stanisław, G., \& Tkacova, A. (2017). The composite coincident indicator (CCI) for business cycles. Acta Polytechnica Hungarica, 14(7), 71-90.

Bretyn, A. (2013). Globalne tendencje współczesnej konsumpcji a racjonalność zachowań konsumentów w Polsce. Studia Ekonomiczne, 139, 69-82.

Cheba K. (2015). The influence of clusters on economic development. A comparative analysis of cluster policy in the European Union and Japan. Oeconomia Copernicana. 6(3), 73-88.

Cheba K., \& Szopik-Depczyńska K. (2017). Multidimensional comparative analysis of the competitive capacity of the European Union countries and geographical regions. Oeconomia Copernicana, 8(4), 487-504. 
Dmytrów, K., \& Bieszk-Stolorz, B. (2019). Mutual relationships between the unemployment rate and the unemployment duration in the Visegrad Group countries in years 2001-2017. Equilibrium. Quarterly Journal of Economics and Economic Policy, 14(1), 129-148.

Dudek, H., \& Koszela, G. (2013). Comparison of households' expenditures structures in selected countries of European Union. Acta Scientiarum Polonorum. Oeconomia, 12(3), 5-15.

Fogarassy, C., Nguyen, H. H., Olah, J., \& Popp, J. (2018). Transition management applications to accelerate sustainable food consumption - Comparative analysis between Switzerland and Hungary. Journal of International Studies, 11(3), 31-43.

Gavurova, B., Vagasova, T., \& Kovac, V. (2016). Competitiveness assessment of Slovak Republic Regions. In J. Krajicek, J. Nesleha \& K. Urbanovsky (Eds.), European Financial System 2016. 13th International Scientific Conference of the European Financial Systems: Proceedings of the 13th International Scientific Conference (pp. 175-186). Brno: Masaryk University.

Gavurova, B., Soltes, M., \& Kovac, V. (2017). Application of cluster analysis in process of competitiveness modelling of Slovak Republic regions. Transformations in Business \& Economics, 16(3), 129-147.

Grzega, U. (2015). Dochód i konsumpcja gospodarstw domowych w Polsce i Unii Europejskiej w latach 2004 i 2012. Handel wewnętrzny, 357(4), 124-134.

Hanusik, K., \& Łangowska-Szczęśniak, U. (2017). Uwarunkowania i przejawy różnicowania modelu konsumpcji na Śląsku w latach 2004-2015. Studia i Prace WNEiZ US, 50, 61-74.

Horáková M. (2015). Consumer behavior of college students in the Czech Republic. Journal of Competitiveness, 7(4), 68-85.

Ivanová, E., \& Masárová, J. (2018). Performance evaluation of the Visegrad Group countries. Economic Research-Ekonomska Istraživanja, 31(1), 270-289.

Jakimowicz, A., \& Rzeczkowski, D. (2019). Do barriers to innovation impact changes in innovation activities of firms during business cycle? The effect of the Polish green island. Equilibrium. Quarterly Journal of Economics and Economic Policy, 14(4), 631676.

Jaklič, A., \& Svetličič, M. (2019). China and Central and Eastern European countries within '16+1': Group or bilateral relations? Entrepreneurial Business and Economics Review, $7(2), 83-100$.

Jankiewicz, M. (2018a). Changes of the consumption structure in European countries considering its modernization process. In M. Papież \& S. Śmiech (Eds.), The 12th Professor Aleksander Zelias International Conference on Modelling and Forecasting of SocioEconomic Phenomena. Conference Proceedings (pp. 170-179). Zakopane.

Jankiewicz, M. (2018b). The influence of the disposable income on the consumption structure in European Countries - Spatio-temporal analysis. In M. Staníčková, L. Melecký, E. Kovářová \& K. Dvoroková (Eds.), Proceedings of the $4^{\text {th }}$ International Conference on European Integration 2018 (pp. 537-544). Ostrava: VŠB-Technical University of Ostrava.

Jankiewicz, M. (2018c). Spatio-temporal analysis of the convergence of consumption expenditures in the European Union countries. In C. Brătianu, A. Zbuchea \& A. Viţelar (Eds), Challenging the status quo in management and economics: Strategica International Academic Conference, Sixth Edition (pp: 142-154). Bucharest.

Jankiewicz, M. (2019). The Convergence of Food Expenditures in the European Union Countriesa Spatio-Temporal Approach. Acta Universitatis Lodziensis. Folia Oeconomica, 1(340), 91-106. 
Jankiewicz, M., \& Pietrzak, M.B. (2019). Analysis of changes in the consumption structure of households in the Visegrad countries - food expenditures. In T. Loster \& T. Pavelka (Eds.), The 13th international days of statistics and economics. Conference Proceedings (pp. 568-575). Prague: Libuse Macakova, Melandrium.

Kompa, K., \& Witkowska, W. (2018). Factors affecting men's and women's earnings in Poland. Economic Research-Ekonomska Istraživanja, 31(1), 252-269.

Kravčáková, V. I., \& Kotulič, R. (2015). Theoretical background of financial management in the context of cap subsidies in V4 Countries. Polish Journal of Management Studies, 12(1), 77-86.

Kuc, M. (2017). Is the regional divergence a price for the international convergence. The case of the Visegrad Group. Journal of Competitiveness, 9(4), 50-65.

Kuc-Czarnecka, M., Lo Piano, S., \& Saltelli, A. (2020). Quantitative storytelling in the making of composite indicator. Social Indicators Research. https://doi.org/10.1007/s11205-02002276-0.

Kurowska-Pysz, J., Szczepańska-Woszczyna, K., Štverková, H., \& Kašík, J. (2018). The catalysts of cross-border cooperation development in euroregions. Polish Journal of Management Studies, 18(1), 180-193.

Kusairi, S., Sanusi, N. A., Suriyani, M., Shukri, M., \& Zamri, N. (2019). Financial households' efficacy, risk preference and saving behaviour: Lessons from lower income households in Malaysia. Economics and Sociology, 12(2), 301-318.

Kuśmierczyk, K., \& Piskiewicz, L. (2012). Konsumpcja w Polsce na tle pozostałych krajów Unii Europejskiej. Konsumpcja i Rozwój, 2(3), 78-93.

Landmesser, J. (2019). Differences in income distributions for men and women in the European Union countries. Equilibrium. Quarterly Journal of Economics and Economic Policy, 14(1), 81-98.

Liobikienè, G., \& Juknys, R. (2012). The convergence of household consumption expenditure structure: Implications on environmental impact in Lithuania. Aplinkos Tyrimai, Inžinerija Ir Vadyba, 60(2), 48-57.

Liobikienè, G., \& Mandravickaitè, J. (2013). Convergence of new members of the EU: Changes in household consumption expenditure structure regarding environmental impact during the prosperous period. Environment, Development and Sustainability, 15(2), 407-427.

Łapinska, J. (2016). Determinant factors of intra-industry trade: The case of Poland and its European Union trading partners. Equilibrium. Quarterly Journal of Economics and Economic Policy, 11(2), 251-264.

Michorowski, M. (2017). Zróżnicowanie wydatków na użytkowanie mieszkania i nośniki energii wśród gospodarstw domowych w Polsce. Prace Naukowe Uniwersytetu Ekonomicznego we Wroctawiu, 487, 188-198.

Malkina, M. (2019). Spatial wage inequality and its sectoral determinants: The case of modern Russia. Oeconomia Copernicana, 10(1), 69-87.

Miłek, D. (2018). Spatial differentiation in the social and economic development level in Poland. Equilibrium. Quarterly Journal of Economics and Economic Policy, 13(3), $487-$ 507.

Mikuła, A. (2017). Changes in the structure of households' consumption expenditures in selected countries of the European Union. In V. Alekneviciene, A. Danilowska, C. Forgacs, B. Freytag-Leyer, W. Heijman, E. Horska, B. Mickiewicz, B. Ohlmer, M. Parlinska, I. Pilvere, B. Rivza, A. Saether, R. Schulte, J. Viaene \& A. Zvirbule (Eds.), Proceedings of 
the 2017 International Conference "Economic Science for Rural Development" (pp. 205212). Jelgava, Latvia.

Nowak, P. (2018). Regional variety in quality of life in Poland. Oeconomia Copernicana, 9(3), $381-401$.

Piekut, M. (2013). Konsumpcja w polskich gospodarstwach domowych na tle krajów europejskich. Problemy Zarzadzania, 11(1(40), 23-39.

Piekut, M. (2015). Zmiany w strukturze konsumpcji krajów Grupy Wyszehradzkiej. Kwartalnik Nauk o Przedsiębiorstwie, 35(2), 91-100.

Pawłowski, Z. (1980). Ekonometria. Warszawa: PWN.

Pietrzak M. B., \& Jankiewicz M. (2019). Evaluation of trends in the development of expenditure on services in the Visegrad Group countries. In M. Houda \& R. Remeš (Eds.), 37th International Conference Mathematical Methods in Economics MME 2019 Conference Proceedings (pp. 499-504). University of South Bohemia in České Budějovice, Faculty of Economics.

Pietrzak, M. B., \& Łapińska, J. (2015). Determinants European Union's trade - Evidence from a panel estimation of the gravity model. $E \&$ M Ekonomie a Management, 18(1), 18-27.

Pietrzak, M. B., \& Ziemkiewicz, B. (2018a). Digital economy in the old European Union member states. In T. Loster \& T. Pavelka (Eds.), The 12th International Days of Statistics and Economics. Conference Proceedings (pp. 1431-1439). Prague: Libuse Macakova, Melandrium.

Pietrzak, M. B., \& Ziemkiewicz, B. (2018b). Multiple criteria analysis of digital economy in the European Union Countries. In M. Reiff \& P. Gezik (Eds.), Proceedings of the International Scientific Conference Quantitative Methods in Economics Multiple Criteria Decision Making XIX (pp. 283-290). Trenčianske Teplice: Letra Edu.

Pietrzak, M. B., \& Ziemkiewicz, B. (2019). Digital economy and unemployment in the Visegrad countries at regional level. In T. Loster \& T. Pavelka (Eds.), The 13th International Days of Statistics and Economics. Conference Proceedings (pp. 1197-1205). Prague: Libuse Macakova

Rollnik-Sadowska, E., \& Dąbrowska, E. (2018). Cluster analysis of effectiveness of labour market policy in the European Union. Oeconomia Copernicana, 9(1), 143-158.

Sánchez-López, C., Aceytuno, M. T., \& De Paz-Bañez, M. A. (2019). Inequality and globalisation: Analysis of European countries. Economics and Sociology, 12(4), 84-100.

Shkolnyk, I., Kozmenko, S., Kozmenko, O., \& Mershchii, B. (2019). The impact of economy financialization on the level of economic development of the associate EU member states. Economics and Sociology, 12(4), 43-58.

Simionescu, M., Lazányi, K., Sopková, G., Dobeš, K., \& Balcerzak, A. P. (2017). Determinants of economic growth in V4 Countries and Romania. Journal of Competitiveness, 9(1), 103113.

Simionescu, M., Balcerzak, A. P., Bilan, Y., \& Kotásková, A. (2018). The impact of money on output in Czech Republic and Romania. Journal of Business Economics and Management, 19(1), 20-41.

Skare, M., \& Porada-Rochoń, M. (2019a). Financial and economic development link in transitional economies: A spectral Granger causality analysis 1991-2017. Oeconomia Copernicana, 10(1), 7-35.

Skare, M., \& Porada-Rochoń, M. (2019b). Tracking financial cycles in ten transitional economies 2005-2018 using singular spectrum analysis (SSA) techniques. Equilibrium. Quarterly Journal of Economics and Economic Policy, 14(1), 7-29. 
Szopik-Depczyńska, K., Cheba, K., Bąk, I., Kiba-Janiak, M., Saniuk, S., Dembińska, I., \& Ioppolo, G. (2017). The application of relative taxonomy to the study of disproportions in the area of sustainable development of the European Union. Land Use Policy, 68, 481-491.

Szopik-Depczyńska, K., Kędzierska-Szczepaniak, A., Szczepaniak, K., Cheba, K., Gajda, W., \& Ioppolo, G. (2018a). Innovation in sustainable development: An investigation of the EU context using 2030 agenda indicators. Land Use Policy, 79, 251-262.

Szopik-Depczyńska, K., Cheba, K., Bąk, I., Stajniak, M., Simboli, A., \& Ioppolo G. (2018b). The study of relationship in a hierarchical structure of EU sustainable development indicators. Ecological Indicators, 90, 120-131.

Szwacka-Mokrzycka, J. (2018). The impact of the level of economic development on food consumption in Poland. In V. Alekneviciene, A. Danilowska, C. Forgacs, B. FreytagLeyer, W. Heijman, E. Horska, B. Mickiewicz, B. Ohlmer, M. Parlinska, I. Pilvere, B. Rivza, A. Saether, R. Schulte, J. Viaene \& A. Zvirbule (Eds.), Proceedings of the 2018 International Conference "Economic Science for Rural Development" (pp. 402-408). Jelgava, Latvia.

Šoltés, V., \& Nováková, B. (2016). Assessment of material living conditions by the means of integrated indices in the Visegrad Group. Polish Journal of Management Studies, 13(1), 157-167.

Trębska, J. (2018). Polish households' savings in the financial intersectoral linkages. Equilibrium. Quarterly Journal of Economics and Economic Policy, 13(2), 307-329.

Tvaronavičienè, M., \& Gatautis, R. (2017). Peculiarities of income distribution in selected countries. Economics and Sociology, 10(4), 113-123.

Utzig, M. (2015). Przemiany w strukturze wydatków konsumpcyjnych gospodarstw domowych w Polsce. Konsumpcja i Rozwój, 3(12), 29-40.

Włodarczyk, K. (2016). Serwicyzacja konsumpcji w polskich gospodarstwach domowych. Prace Naukowe Uniwersytetu Ekonomicznego we Wroclawiu, 449, 699-708.

Wójcik, P. (2017). Was Poland the next Spain? Parallel analysis of regional convergence patterns after accession to the European Union. Equilibrium. Quarterly Journal of Economics and Economic Policy, 12(4), 593-611.

Verba, D., \& Kudinova, A. (2019). Absolute value and diversity of household spending: Analysis on International Comparison Program (ICP) 2011 data. Equilibrium. Quarterly Journal of Economics and Economic Policy, 14(1), 99-127.

Victor, V., Thoppan, J. J., Fekete-Farkas, M., \& Grabara, J. (2019). Pricing strategies in the era of digitalisation and the perceived shift in consumer behaviour of youth in Poland. Journal of International Studies, 12(3), 74-91.

Zalega, T. (2011). Mikrouwarunkowania potrzeb i zachowań rynkowych gospodarstw domowych a nowa konsumpcja. Studia i Materiaty, 1-2(12-13), 79-106.

Zalega, T. (2013). Nowe trendy i makrotrendy w zachowaniach konsumenckich gospodarstw domowych w XXI w. Konsumpcja i rozwój, 2(5), 3-21. 